\title{
Studies on $\mathrm{H}_{2}$-Assisted Liquefied Petroleum Gas Reduction of $\mathrm{NO}$ over $\mathrm{Ag} / \mathrm{Al}_{2} \mathrm{O}_{3}$ Catalyst
}

\author{
Pratichi Singh ${ }^{1}$, Deepak Yadav ${ }^{2}$, Pooja Thakur ${ }^{2}$, Jitendra Pandey ${ }^{1}$, R. Prasad ${ }^{2 *}$ \\ ${ }^{1}$ Department of Environmental Science, Institute of Sciences, BHU, Varanasi 221005, India \\ ${ }_{2}^{2}$ Department of Chemical Engineering and Technology, IIT (BHU), Varanasi 221005, India
}

Received: 24th June 2017; Revised: $6^{\text {th }}$ October 2017; Accepted: 10 th November 2017;

Available online: 11 $1^{\text {st }}$ June 2018; Published regularly: 1st August 2018

\begin{abstract}
Hydrocarbon-Selective catalytic reduction (HC-SCR) is one of the potential methods to remove $\mathrm{NO}_{\mathrm{x}}$ emissions from diesel engine, lean burn petrol engines and natural gas engines exhaust. $\mathrm{Ag} / \mathrm{Al}_{2} \mathrm{O}_{3}$ is a good catalyst for $\mathrm{HC}$-SCR of $\mathrm{NO}_{\mathrm{x}}$ under lean-burn conditions. Further, addition of small amount of $\mathrm{H}_{2}$ is effective for enhancing HC-SCR activity. This effect is unique to silver and to specific $\mathrm{Ag} /$ support combinations, namely, $\mathrm{Ag} / \gamma-\mathrm{Al}_{2} \mathrm{O}_{3}$. Various $\mathrm{HC}$ reductants, such as: octane, decane, dodecane and propane, have been reported in the literatures. Only a single study on LPG as a reductant over Cu-ZSM catalyst was reported. There was no work reported on $\mathrm{H}_{2}$ assisted LPG over $\mathrm{Ag} / \mathrm{Al}_{2} \mathrm{O}_{3}$ catalyst. Thus, this gap in the literature is filled with the present investigation of NO reduction over 2 wt.\% $\mathrm{Ag} / \mathrm{Al}_{2} \mathrm{O}_{3}$ catalyst using LPG reductant. The fresh and used catalyst was characterized by various techniques like low temperature $\mathrm{N}_{2}$-adsorption, XRD, XPS and SEM. There was practically no change in the characteristics of the fresh and used catalyst. Two different reductants of CO and LPG were compared for SCR of NO over the catalyst without and with $\mathrm{H}_{2}$-assisted. The experiments were performed in a fixed bed tubular flow reactor under the following conditions: $100 \mathrm{mg}$ catalyst; $0.13 \% \mathrm{NO}, 2.5 \% \mathrm{LPG} / \mathrm{CO}, 1 \% \mathrm{H}_{2}, 10 \% \mathrm{O}_{2}$, rest Ar; total flow rate $60 \mathrm{~mL} / \mathrm{min}$; temperature ambient $400{ }^{\circ} \mathrm{C}$ and pressure $1 \mathrm{~atm}$. Around $100 \%$ conversion of NO was achieved using LPG reductant. Light off temperature of NO reduction significantly reduced by $\mathrm{H}_{2}$ assisted LPG reductant. The maximum conversion of $\mathrm{NO}$ with $\mathrm{CO}$ was limited to $35.15 \%$ at temperature of $224^{\circ} \mathrm{C}$ and above. Whereas, $97.79 \% \mathrm{NO}$ conversion was achieved at $365^{\circ} \mathrm{C}$ with $\mathrm{LPG}$ reductant. While, the maximum conversions with $\mathrm{H}_{2}-\mathrm{LPG}$ and $\mathrm{H}_{2}$-CO reductants were 100 and $99.46 \%$ at 117 and $220{ }^{\circ} \mathrm{C}$, respectively. Therefore, $\mathrm{H}_{2}-\mathrm{LPG}-\mathrm{SCR}$ of $\mathrm{NO}_{\mathrm{x}}$ over 2 wt.\% $\mathrm{Ag} / \mathrm{Al}_{2} \mathrm{O}_{3}$ catalyst system can be used to get $100 \%$ reduction at low temperature. Copyright (C) 2018 BCREC Group. All rights reserved
\end{abstract}

Keywords: $\mathrm{Ag} / \mathrm{Al}_{2} \mathrm{O}_{3} ; \mathrm{H}_{2}$-assisted SCR; $\mathrm{NO}_{\mathrm{x}}$ reduction; LPG reductant; Lean-burn engines

How to Cite: Singh, P., Yadav, D., Thakur, P., Pandey, J., Prasad, R. (2018). Studies on $\mathrm{H}_{2}$-Assisted Liquefied Petroleum Gas Reduction of $\mathrm{NO}$ over $\mathrm{Ag} / \mathrm{Al}_{2} \mathrm{O}_{3}$ Catalyst. Bulletin of Chemical Reaction Engineering \& Catalysis, 13 (2): 227-235 (doi:10.9767/bcrec.13.2.1307.227-235)

Permalink/DOI: https://doi.org/10.9767/bcrec.13.2.1307.227-235

\section{Introduction}

Selective catalytic reduction (SCR) is a potential method to remove $\mathrm{NO}_{\mathrm{x}}$ under excess oxygen conditions such as diesel engine exhausts and lean burn engines. The two main aspects of SCR are reducing agent and $\mathrm{NO}_{\mathrm{x}}$ reduction catalyst. Urea and ammonia are most exten-

* Corresponding Author.

E-mail: sysjzx@126.com (Z.X. Ji),

Telp: +86-536-8785613, Fax: +86-536-8785613 sively used reductants. However, urea-SCR technology has serious drawbacks, such as an additional urea tank to be refilled periodically, heated to avoid freezing of the urea solution (urea-SCR) [1], and formation of high molecular weight products. Ergo, now a day hydrocarbons (HC) like those typically present in fuel mixtures are used as a reductant, such as: octane, decane, dodecane and propane [2-4], etc. Among the catalyst for $\mathrm{NO}_{\mathrm{x}}$ reduction most extensively researched HC-SCR of $\mathrm{NO}_{\mathrm{x}}$ catalysts are $\mathrm{Ag} / \mathrm{Al}_{2} \mathrm{O}_{3}$. It is amongst the most active and se- 
lective catalyst in both laboratory and full-scale tests $[5,6]$. It has become clear that $\mathrm{Ag} / \mathrm{Al}_{2} \mathrm{O}_{3}$ catalysts have several key advantages over other potential diesel-SCR catalysts, i.e. $\mathrm{Cu}$ ZSM5 and $\mathrm{Pt} / \mathrm{Al}_{2} \mathrm{O}_{3}$. Such advantages include low activity for $\mathrm{SO}_{2}$ oxidation, relatively high thermal and hydrothermal durability (compared to $\mathrm{Cu}$-ZSM5) and high selectivity to $\mathrm{N}_{2}$ (contrasting Pt-based catalysts which form considerable quantities of $\mathrm{N}_{2} \mathrm{O}$ ) $[7,8]$. Further, addition of minute amount of $\mathrm{H}_{2}$ to the reductant leads to a significant increase in $\mathrm{NO}_{\mathrm{x}}$ reduction efficiency in presence of $\mathrm{Ag} / \mathrm{Al}_{2} \mathrm{O}_{3}$ catalyst. This effect is unique to silver and to specific $\mathrm{Ag} /$ support combinations, namely $\mathrm{Ag} / \gamma$ $\mathrm{Al}_{2} \mathrm{O}_{3}$ and $\mathrm{Ag} / \mathrm{MFI}[2,9]$.

The role of each silver site in $\mathrm{Ag} / \mathrm{Al}_{2} \mathrm{O}_{3}$ catalyst is much discussed topic leading to several articles [10-13], it is generally accepted that metallic silver has an oxidizing function and is thus responsible for activation of $\mathrm{HC}$ and $\mathrm{NO}_{\mathrm{x}}$. Small silver clusters and oxidized silver have been proposed to activate the $\mathrm{NO}_{\mathrm{x}}$ reduction activity by partially oxidizing the reductant and promoting surface nitrate formation. Shimizu and Satsuma have summarized various silver states as active sites in their review and references therein [14]. The proportion of small silver clusters and metallic silver depends much on the silver loading and preparation technique. With impregnation methods, high silver loading tends to produce more metallic silver while low silver loading gives a higher proportion of small clusters of silver [15]. Sol-gel methods produce catalysts containing small silver clusters and oxidized silver which are more finely distributed in the alumina matrix $[16,17]$.

One of the most challenging part in HC-SCR over $\mathrm{Ag} / \mathrm{Al}_{2} \mathrm{O}_{3}$ catalysts is to understand the reaction mechanism of $\mathrm{NO}_{\mathrm{x}}$ reduction, which is particularly complicated by the nature of hydrocarbons used that contribute to the formation of a number of intermediates (both spectators and active intermediates) during reaction. Several literature reports have addressed mechanistic aspects of $\mathrm{NO}_{\mathrm{x}}$ reduction over $\mathrm{Ag} / \mathrm{Al}_{2} \mathrm{O}_{3}$ [18-21]. Generally, the first step of $\mathrm{HC}-\mathrm{SCR}$ is activation of $\mathrm{NO}$ and $\mathrm{HC}$ by $\mathrm{O}_{2}$. NO and $\mathrm{O}_{2}$ form $\mathrm{NO}_{\mathrm{x}}$ surface species (nitrates and nitrites). Strongly adsorbed nitrate is known to self-inhibit the $\mathrm{NO}_{\mathrm{x}}$ reduction at low temperature $[22,23]$. For activation of $\mathrm{HC}$, the $\mathrm{O}_{2}$ partially oxidizes the $\mathrm{HC}$ to form oxygenated $\mathrm{HC}$ surface components. Although the formation of oxygenated $\mathrm{HC}$ is generally agreed to occur, however, the structure and role of oxygenated $\mathrm{HC}$ surface compounds remains a subject of de- bate in the literature [24].

Addition of hydrogen promotes the following reactions over $\mathrm{Ag} / \mathrm{Al}_{2} \mathrm{O}_{3}$ : (1) oxidation of $\mathrm{NO}$ to nitrate; (2) oxidation of NO to $\mathrm{NO}_{2}$; (3) partial oxidation of $\mathrm{C}_{3} \mathrm{H}_{8}$ to acetone; and (4) oxidation of acetone with $\mathrm{NO}+\mathrm{O}_{2}$ mixture [19,25-27]. Some research groups believed that the catalytic activity was promoted by the reductive activation of $\mathrm{O}_{2}$ with $\mathrm{H}_{2}$ and the production of moderately agglomerated $\mathrm{Ag}_{\delta+n}$ clusters on the catalyst surface [28]. Wichterlova and coworkers [29] proposed that hydrogen itself participates directly in the reaction mechanism. Similarly, Breen and co-workers [29] also investigated that "hydrogen effect" is due to a chemical effect and not the result of a change in the structure of the active site. Shibata et al. [30] claim that the rate of $\mathrm{NO}_{\mathrm{x}}$ reduction in the SCR reaction is directly dependent on the rate of partial oxidation of the hydrocarbon to surface acetate and that hydrogen has a remarkable effect in promoting this oxidation reaction.

Wang et al. [31] studied SCR of $\mathrm{NO}_{\mathrm{x}}$ over various trace noble metals ( $\mathrm{Pt}, \mathrm{Au}$, or $\mathrm{Pd}$ ) coimpregnated with $\mathrm{Ag} / \mathrm{Al}_{2} \mathrm{O}_{3}$ catalysts and found that addition of small quantity of $\mathrm{Pd}$ to $\mathrm{Ag} / \mathrm{Al}_{2} \mathrm{O}_{3}$ enhances $\mathrm{NO}_{\mathrm{x}}$ reduction efficiency. D'Agostino et al. [32] have studied the SCR of NOx in the presence of various reducing agents, namely toluene, n-octane and ethanol, over $\mathrm{Ag} / \mathrm{Al}_{2} \mathrm{O}_{3}$ prepared by standard wet impregnation. In this paper they described a simple approach to characterizing the interaction energy of water and reducing agent so as to aid the selection of reducing agent and catalyst to be used in SCR conversions and found that reducing agents with weaker strength of surface interaction relative to water, such as hydrocarbons, show poorer activity compared to reducing agents with stronger strength of interaction, such as ethanol. Yu et al. [33] reported that $\mathrm{NO}_{\mathrm{x}}$ reduction by hydrocarbons containing two- or three-carbon atoms was clearly promoted by $\mathrm{H}_{2}$ at low temperatures, while this promotion effect of $\mathrm{H}_{2}$ did not occur during the $\mathrm{CH}_{4}$-SCR over $\mathrm{Ag} / \mathrm{Al}_{2} \mathrm{O}_{3}$.

Therefore, in the present study LPG consisting $\sim 72 \% \mathrm{C}_{3} \mathrm{H}_{8}$ was used as a reductant. The potential use of LPG as reducing agent in the $\mathrm{SCR}$ of $\mathrm{NO}_{\mathrm{x}}$ is a better alternative to the other reductants as it leads to a strong decrease in the Gibbs free energy values of NO reduction to $\mathrm{N}_{2}$ than other reductants [34]. Several advantageous features of LPG such as economical, portable, gaseous nature and readily available around the globe make it possible choice of lean de- $\mathrm{NO}_{\mathrm{x}}$ reductant over gasoline and diesel or other $\mathrm{HC}$ reductants. However, there is very 
limited literature is available for the use of liquefied petroleum gas (LPG) as a reductant [35].

Keeping in view the advantages of LPG and that fact that there is very limited literature available for the use of LPG as a reductant in $\mathrm{SCR}$ of $\mathrm{NO}_{\mathrm{x}}$, the present investigation was undertaken to evaluate LPG-SCR of lean $\mathrm{NO}_{\mathrm{x}}$ over $\mathrm{Ag} / \mathrm{Al}_{2} \mathrm{O}_{3}$ catalyst. To create a better understanding of the effect of reductants as well as $\mathrm{H}_{2}$ addition to the reductant, $\mathrm{CO}$ and LPG with and without $\mathrm{H}_{2}$ was also investigated over the $\mathrm{Ag} / \mathrm{Al}_{2} \mathrm{O}_{3}$ catalysts.

\section{Materials and Method}

\subsection{Catalyst preparation}

The $\mathrm{Ag} / \mathrm{Al}_{2} \mathrm{O}_{3}$ catalyst containing 2 wt.\% $\mathrm{Ag}$ was prepared by wet-impregnation of commercial $\gamma-\mathrm{Al}_{2} \mathrm{O}_{3}$ (Alfa Aesar, surface area 255 $\left.\mathrm{m}^{2} \cdot \mathrm{g}^{-1}\right)$ with an aqueous solution of $\mathrm{AgNO}_{3}$ [36]. The precursor solution of the catalyst was dried overnight at $110{ }^{\circ} \mathrm{C}$ and calcined at $500{ }^{\circ} \mathrm{C}$ for 1 h.

\subsection{Catalyst characterization}

The 2 wt.\% $\mathrm{Ag} / \mathrm{Al}_{2} \mathrm{O}_{3}$ catalyst was characterized before and after the activity measurements by following techniques:

\subsubsection{Textural characterization}

BET surface area of the catalysts was measured by low temperature nitrogen adsorption at

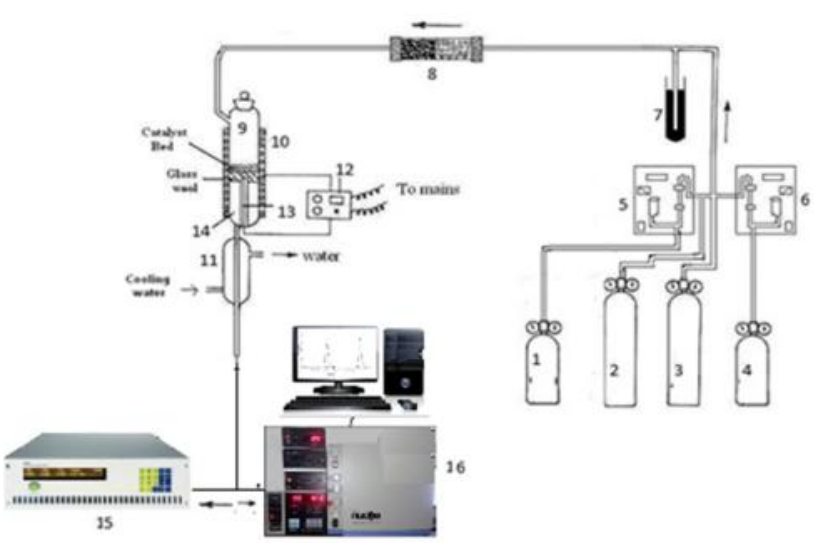

Figure 1. Experimental setup for SCR of NO over $\mathrm{Ag} / \mathrm{Al}_{2} \mathrm{O}_{3}$ catalysts: 1 . NO cylinder, 2. Air cylinder, 3 . Ar cylinder, 4. Reductant $\left(\mathrm{H}_{2}, \mathrm{LPG}\right.$, $\mathrm{CO})$ cylinder, 5. Digital gas flow meter, 6 . Digital gas flow meter, 7. Hg safety device, 8. Moisture trap, 9. Reactor, 10. Split open furnace, 11. Condenser, 12. Microprocessor temperature controller, 13. Thermocouple, 14. Thermowell, 15. Chemiluminescence $\mathrm{NO} / \mathrm{NO}_{\mathrm{x}}$ analyzer, 16 . Gas chromatograph
$-196{ }^{\circ} \mathrm{C}$ using a Micromeritics ASAP 2020 analyzer. Samples were degassed at $300{ }^{\circ} \mathrm{C}$ under vacuum prior to the measurement. The calculation was performed using the adsorption data in the relative pressure $\left(p / p_{0}\right)$ range from 0.05 to 0.30 , and the total volumes were determined from the amounts adsorbed at relative pressure, $p / p_{o}=0.99$. The pore size distribution was calculated based on the desorption curve of the isotherm using the Barrett-Joyner-Halenda (BJH) algorithm. The average pore diameter was defined as the position of the maximum in the pore-size distribution curve.

\subsubsection{X-ray diffraction (XRD)}

XRD measurements were conducted using a Rigaku Miniex DMAX-B diffractometer with a $\mathrm{Cu}$-Ka radiation source, operated at $40 \mathrm{kV}$ and $100 \mathrm{~mA}$. Patterns were recorded in the $\theta$ range from $20^{\circ}$ to $90^{\circ}$ at $4 \%$ minute. The diffraction patterns have been indexed by comparison with the JCPDF files.

\subsubsection{X-Ray Photoelectron Spectroscopy (XPS)}

XPS was performed on an Amicus scanning Auger microprobe using $\mathrm{Mg}-\mathrm{K} a \mathrm{X}$-ray source $\left(h_{c}=1253.6 \mathrm{eV}\right)$ at a base pressure of $3 \times 10^{-8}$ mbar operated at $120 \mathrm{~W}$. The binding energies were calibrated using $\mathrm{C}$ 1s peak of contaminant carbon $(\mathrm{BE}=284.6 \mathrm{eV})$ as standard, and quoted with a precision of $\pm 0.2 \mathrm{eV}$. The collected data were analyzed using a nonlinear Shirley-type background. Atomic concentrations were evaluated by normalizing peak areas to the Scofield sensitivity factors.

\subsubsection{Scanning Electron Microscopy (SEM)}

Scanning electron micrographs (SEM) were recorded on Zeiss EVO 18 scanning electron microscope (SEM) instrument. An accelerating voltage of $15 \mathrm{kV}$ and magnification of $1000 \mathrm{X}$ was applied.

\subsection{Catalyst activity measurement}

SCR of NO experiments were performed in a tubular reactor mounted in a split open tube furnace under the following conditions: $100 \mathrm{mg}$ catalyst; gas composition consisting of 1250 ppm NO, 2.5\% LPG/CO, $1 \% \mathrm{H}_{2}, 10 \% \mathrm{O}_{2}$, rest Ar; total gas flow rate $60 \mathrm{~mL} / \mathrm{min}$; temperature from ambient to $400{ }^{\circ} \mathrm{C}$ and pressure $1 \mathrm{~atm}$. The experimental setup used for the catalytic activity measurement is shown in Figure 1. It can be divided into following sections: feeding system consisting of gas cylinders and digital 
flow meters, tubular fixed bed reactor in split open furnace.

The compositions of inlet and outlet gases were measured with the help of an online gas chromatograph (Nucon, series-5765) and NO analyzer (Eco Physics CLD 62 chemiluminescence $\mathrm{NO} / \mathrm{NO}_{\mathrm{x}}$ ). The $\mathrm{CO}, \mathrm{CO}_{2}$, and $\mathrm{N}_{2}$ concentrations were measured by GC equipped with porapack Q-column/molecular sieve 5-A, methanizer, and FID/TCD detector. The temperature of the catalyst bed was measured using a K-type thermocouple. The measurement was done at steady state condition. The percent conversion of $\mathrm{NO}$ and $\mathrm{CO}$ was calculated by Equations 1 and 2, respectively.

$$
\begin{aligned}
& N O_{\text {Conversion }}(\%)=\frac{\left[N O_{\text {inlet }}\right]-\left[N O_{\text {outlet }}\right]}{\left[N O_{\text {inlet }}\right]} \times 100 \\
& C O_{\text {Conversion }}(\%)=\frac{\left[C O_{\text {inlet }}\right]-\left[C O_{\text {outlet }}\right]}{\left[C O_{\text {inlet }}\right]} \times 100
\end{aligned}
$$

where, $\left[N O_{\text {inlet }}\right]$ and $\left[N O_{\text {outlet }}\right]$ are concentrations of $\mathrm{NO}$ at the inlet and outlet of the reactor, respectively. Similarly, $\left[\mathrm{CO}_{\text {inlet }}\right]$ and $\left[\mathrm{CO}_{\text {outlet }}\right]$ are concentrations of $\mathrm{CO}$ at the inlet and outlet of the reactor, respectively.

Table 1. Textural characterization of $\mathrm{Ag} / \mathrm{Al}_{2} \mathrm{O}_{3}$ catalyst

\begin{tabular}{cccc}
\hline Catalyst & $\begin{array}{c}\text { Surface area } \\
\left(\mathrm{m}^{2} / \mathrm{g}\right)\end{array}$ & $\begin{array}{c}\text { Pore volume } \\
\left(\mathrm{cm}^{3} / \mathrm{g}\right)\end{array}$ & $\begin{array}{c}\text { Avg. pore } \\
\text { diameter } \\
(\AA)\end{array}$ \\
\hline $\begin{array}{c}\mathrm{Ag} / \mathrm{Al}_{2} \mathrm{O}_{3} \\
(\mathrm{Fresh})\end{array}$ & 93.13 & 0.151 & 64.80 \\
$\begin{array}{c}\mathrm{Ag} / \mathrm{Al}_{2} \mathrm{O}_{3} \\
(\mathrm{Used})\end{array}$ & 90.14 & 0.139 & 60.19 \\
\hline
\end{tabular}

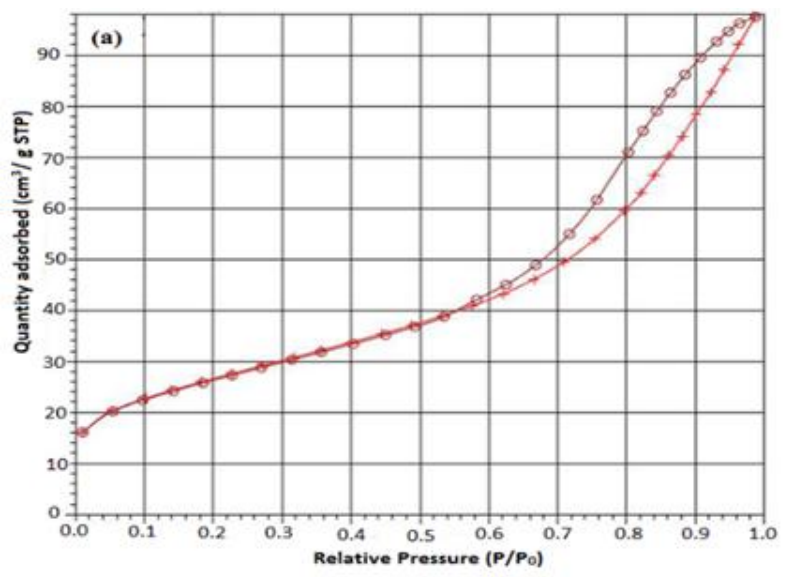

\section{Results and Discussion}

\subsection{Catalyst characterization}

\subsubsection{Textural properties}

The typical isotherms of fresh and used $\mathrm{Ag} / \mathrm{Al}_{2} \mathrm{O}_{3}$ catalyst is shown in Figure 2 and textural properties are shown Table 1. It is of type IV isotherms according to IUPAC classification 1984, exhibit mesoporous pore size. $\mathrm{In} \mathrm{Ag} / \mathrm{Al}_{2} \mathrm{O}_{3}$ catalyst hysteresis loops occur at low relative pressures ( 0.6) suggesting that catalyst contains cylindrical pores.

\subsubsection{X-ray diffraction (XRD)}

XRD pattern of $\mathrm{Ag}-\mathrm{Al}_{2} \mathrm{O}_{3}$ composite are shown in Figure 3. In XRD patterns of the catalyst much significant, sharper and broad peak of $\mathrm{Al}_{2} \mathrm{O}_{3}$ was observed at $2 \theta=67.18^{\circ}$ and $46.22^{\circ}$. The $\mathrm{Ag}$ phase was observed at $2 \theta=$ $37.2^{\circ}$ which correspond to the (111) lattice planes of metallic Ag, this might because that $\mathrm{Ag}$ species on the $\mathrm{Ag}-\mathrm{Al}_{2} \mathrm{O}_{3}$ was crystalline phase (JCPDS 04-0783). Significant peak at $2 \theta$ $=32.4^{\circ}$ indicates presence of $\mathrm{Ag}_{2} \mathrm{O}$ (111) phases in the sample (JCPDS 41-1104). The crystallite size of the catalyst was $1.0154 \AA$ determined using Debye-Scherrer equation (Equation 3).

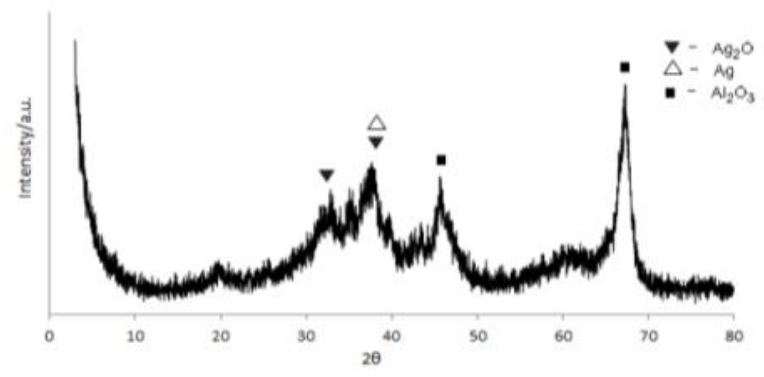

Figure 3. XRD pattern of $2 \% \mathrm{Ag} / \mathrm{Al}_{2} \mathrm{O}_{3}$

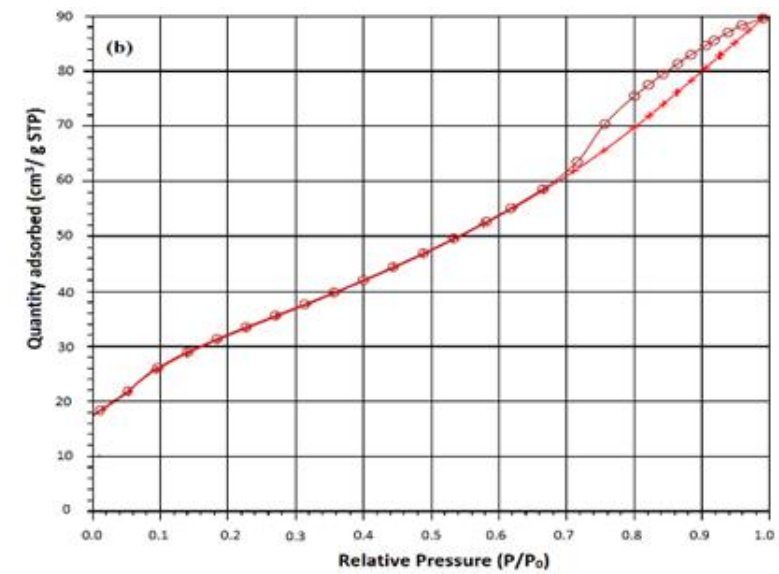

Figure 2. Nitrogen adsorption-desorption isotherms on $\mathrm{Ag} / \mathrm{Al}_{2} \mathrm{O}_{3}$ : (a) Fresh, (b) Used catalyst 


$$
d=0.89 \lambda / \beta \cos \theta
$$

where, $d$ is the mean crystallite diameter $(\AA), \lambda$ is the X-ray wave length $(1.54056 \AA), \beta$ is the full width half maximum (FWHM) and $\theta$ is the Bragg-angle.

\subsubsection{X-Ray Photoelectron Spectroscopy (XPS)}

The $\mathrm{Ag}$ valence state of the supported $\mathrm{Ag}$ was characterized by high-resolution XPS, with the results shown in Figure 4 and summarized in Table 2. As can be seen in figure, the peaks of the $\mathrm{Ag} 3 \mathrm{~d}_{5 / 2}$ binding energy for sample appeared at around 368.8-370.3 eV. This suggests that there are two different states of metallic silver on the surface, where the difference in binding energy between the two states can be explained by the difference of the charge effect. As reported by Hammond et al. [37] Ag is unusual in that its core-level photoemissions shift to lower binding energy with increasing oxidation state. The binding energy of $\mathrm{Ag} 3 \mathrm{~d}_{5 / 2}$ in $\mathrm{Ag}$ $\mathrm{Al}_{2} \mathrm{O}_{3}$, is 368.0 , which are consistent with the

Table 2. Binding energy of $\mathrm{Ag} / \mathrm{Al}_{2} \mathrm{O}_{3}$ elements

\begin{tabular}{ccc}
\hline Catalyst & Components & Binding energy $(\mathrm{eV})$ \\
\hline $\mathrm{Ag} / \mathrm{Al}_{2} \mathrm{O}_{3}$ & $\mathrm{Ag} 3 \mathrm{~d}_{5 / 2}$ & 371.9 \\
& & 377.2 \\
& $\mathrm{Al} 3 \mathrm{~d}_{5 / 2}$ & 77 \\
& $\mathrm{O} 1 \mathrm{~s}$ & 535 \\
\hline
\end{tabular}
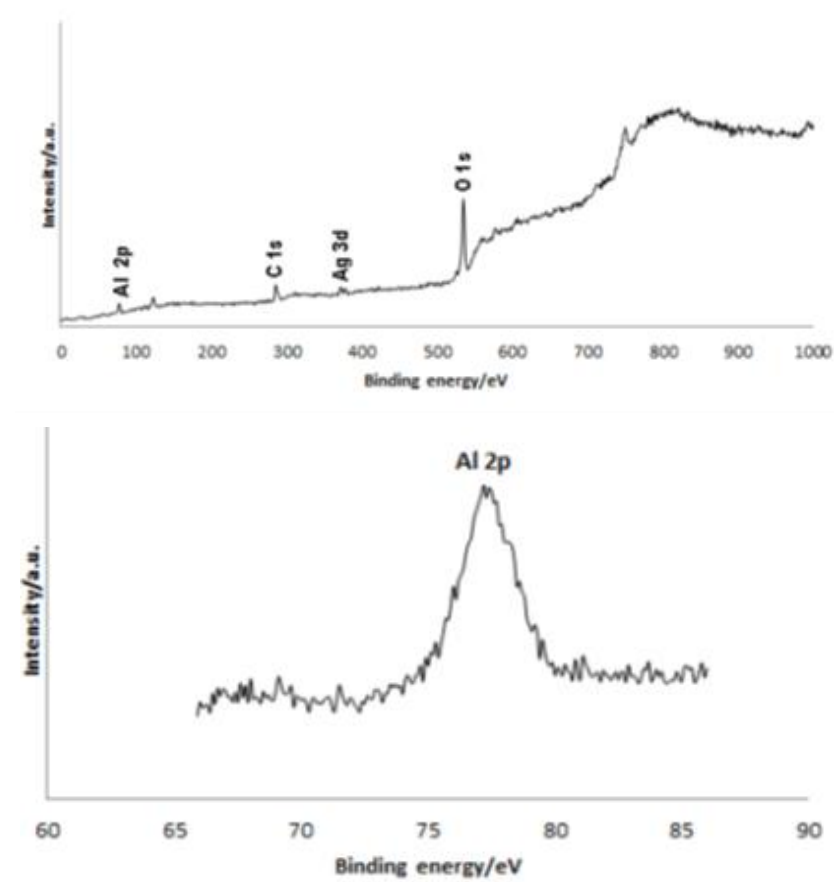

binding energies of $\mathrm{Ag} 3 \mathrm{~d}_{5 / 2}$ in $\mathrm{Ag}_{2} \mathrm{O}$, according to the literature values of $367.9 \mathrm{eV}$ [37]. In addition, a shoulder at $368.5 \mathrm{eV}$ for $\mathrm{Ag} / \mathrm{Al}_{2} \mathrm{O}_{3}$ might be attributed to $\mathrm{Ag}^{0}\left(\mathrm{Ag} 3 \mathrm{~d}_{5 / 2}=368.4 \mathrm{eV}\right)$ on the surface. Binding energy of $\mathrm{Al} 2 \mathrm{p}_{3 / 2}$ in $\mathrm{Ag}$ $\mathrm{Al}_{2} \mathrm{O}_{3}$ appeared at $77.6 \mathrm{eV}$ which might be binding energy of $\mathrm{Al}_{2} \mathrm{O}_{3}$.

\subsubsection{Scanning Electron Microscopy (SEM)}

The SEM micrographs of fresh and used $\mathrm{Ag} / \mathrm{Al}_{2} \mathrm{O}_{3}$ catalysts is presented in Figure 5. The results are shown in the figure at magnification of $500 \mathrm{X}$. Agglomerates of $\mathrm{Y}-\mathrm{Al}_{2} \mathrm{O}_{3}$ particles can be observed in SEM image of amorphous $\gamma-\mathrm{Al}_{2} \mathrm{O}_{3}$ in accordance with its pore volume $\left(0.151 \mathrm{~cm}^{3} / \mathrm{g}\right)$. At lower magnification the pictures reveal that $\mathrm{Al}_{2} \mathrm{O}_{3}$ clusters are almost regular spherical shape with diameters of 50 $150 \mu \mathrm{m}$. The black shades surrounding the grey particles represent the fine inter-particles pores. At higher magnification intra-particles pores can be clearly visualized in the micrograph. Fine white and grey crystals clearly indicated that the silver was present in the metallic and oxide form respectively on $\mathrm{Al}_{2} \mathrm{O}_{3}$ surface at higher magnification. It is clear that silver was present in dispersed sate. Thus, SEM results are also in good agreement with that of the XRD findings. There was no noticeable change in the characteristics of the fresh and used 2 wt. $\% \mathrm{Ag} / \mathrm{Al}_{2} \mathrm{O}_{3}$ catalyst under the conditions studied in the present investigation.

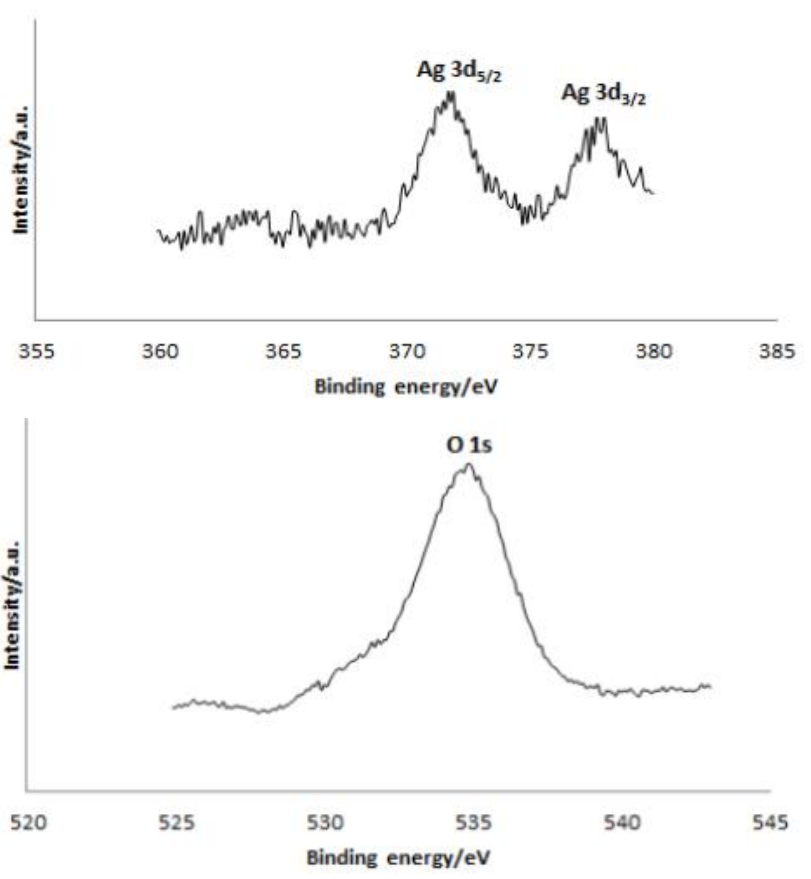

Figure 4. XPS spectra of $\mathrm{Ag} / \mathrm{Al}_{2} \mathrm{O}_{3}$ elements 


\subsection{Catalyst activity measurement}

\subsubsection{Effect of CO and LPG reductant over $\mathrm{Ag} / \mathrm{Al}_{2} \mathrm{O}_{3}$}

As the feed gas in the present study contained two different reductants over $\mathrm{Ag} / \mathrm{Al}_{2} \mathrm{O}_{3}$ catalysts, both kind of the reductant might contribute to the overall NO conversion [38]. In order to elucidate the individual effect of each kind of reductants and catalysts on the catalytic performance, first $\mathrm{NO}$ conversion over $\mathrm{Ag} / \mathrm{Al}_{2} \mathrm{O}_{3}$ catalyst with LPG as well as $\mathrm{CO}$ was compared. It is very clear from the Figure 6 that the activity of the catalyst was greatly influenced by the type of reductant. The maximum conversion of $\mathrm{NO}$ with $\mathrm{CO}$ reductant was $35.15 \%$, while this value $(97.79 \%)$ is relatively very high in case of LPG reductant. NO conversion with LPG reductant increased to the maximum conversion of $97.79 \%$ in two steps. In the first step $30 \%$ NO conversion was achieved at $269{ }^{\circ} \mathrm{C}$. In the second step, with slight increase in temperature, conversion was suddenly in-

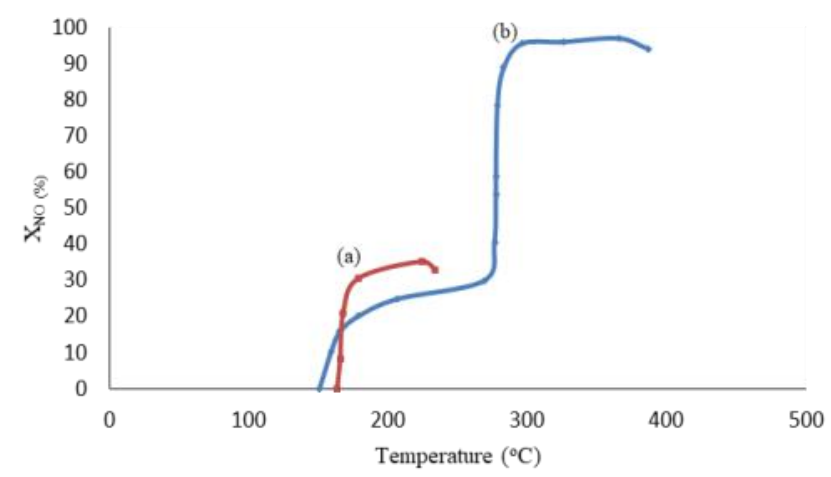

Figure 6. $\mathrm{NO}$ conversion over $\mathrm{Ag} / \mathrm{Al}_{2} \mathrm{O}_{3}$ catalyst with (a) CO and (b) LPG

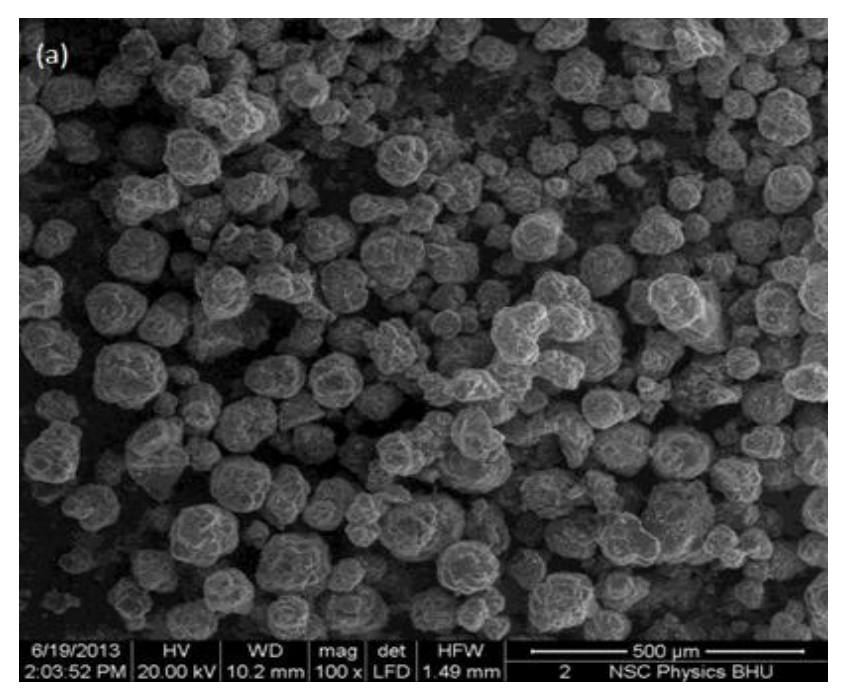

creased to the steady-state value of $97.79 \%$ in the temperature range 296-366 ${ }^{\circ} \mathrm{C}$. After 366 ${ }^{\circ} \mathrm{C}$ NO conversion was decreased. Therefore, it is evident that LPG is better reductant than $\mathrm{CO}$ for $\mathrm{NO}$ conversion over $\mathrm{Ag}-\mathrm{Al}_{2} \mathrm{O}_{3}$ catalyst.

\subsubsection{Effect of $\mathrm{H}_{2}$ addition on $\mathrm{CO}$ and $\mathrm{LPG}$ re-} ductant over $\mathrm{Ag} / \mathrm{Al}_{2} \mathrm{O}_{3}$

Figure 7 shows the NO reduction with $\mathrm{CO}$ and LPG reductants over $\mathrm{Ag}-\mathrm{Al}_{2} \mathrm{O}_{3}$ catalyst in presence and absence of $\mathrm{H}_{2}$. It is clearly observed that the addition of hydrogen in feed stream has remarkable effect on the activity of the catalyst with $\sim 95 \%$ reduction below $100{ }^{\circ} \mathrm{C}$. Though 100\% conversion could be achieved with both the reductants but occurs at different temperatures. The maximum conversion of $100 \%$ of $\mathrm{NO}$ in presence of $\mathrm{H}_{2}$ could be achieved with both the reductant. The temperature range for $100 \%$ NO reduction with CO reductant is narrower $\left(108-160^{\circ} \mathrm{C}\right)$ than $\mathrm{LPG}$ reductant. The maximum conversion with $\mathrm{CO}$ reductant without $\mathrm{H}_{2}$ was only $35 \%$ at $224{ }^{\circ} \mathrm{C}$, whereas in presence of $\mathrm{H}_{2}$ this value is $100 \%$ at far below lower temperature of $108{ }^{\circ} \mathrm{C}$.

With LPG reductant also 100\% NO conversion could be achieved in presence of $\mathrm{H}_{2}$ as well as in absence of $\mathrm{H}_{2}$ at different temperatures (Figure 7). The 100\% conversion with LPG reductant in presence of $\mathrm{H}_{2}$ was achieved at far lower temperature $\left(220{ }^{\circ} \mathrm{C}\right)$ than without $\mathrm{H}_{2}$ at $366{ }^{\circ} \mathrm{C}$. Reduction of NO with LPG also gives $97 \%$ conversion at the temperature $367{ }^{\circ} \mathrm{C}$ but the addition of hydrogen decreases the temperature approximately $150{ }^{\circ} \mathrm{C}$.

Table 3 summarizes the experimental results for the catalyst tested using CO and LPG as reductant in presence and absence of $\mathrm{H}_{2}$ to

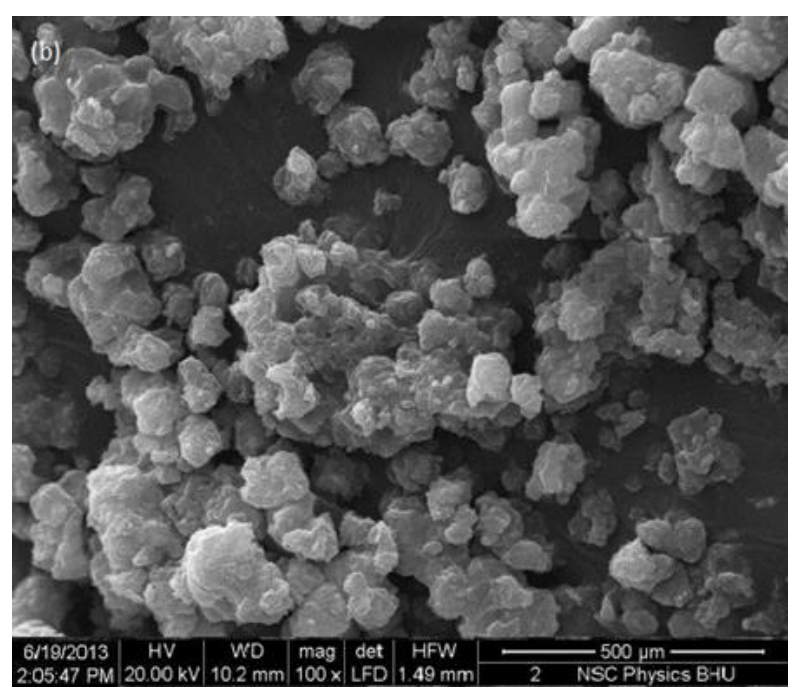

Figure 5. SEM micrographs of $\mathrm{Ag} / \mathrm{Al}_{2} \mathrm{O}_{3}$ catalyst at different magnifications: a) fresh, b) used 
the feed showing characteristic temperatures ( $T_{i}$ and $T_{\max }$ ) for NO reduction. Complete NO conversion could be achieved specifically in presence of $\mathrm{H}_{2}$. The table shows that $\mathrm{Ag}-\mathrm{Al}_{2} \mathrm{O}_{3}$ catalyst initiation $\left(T_{i}\right)$ as well as total NO conversion $\left(T_{\max }\right)$ occurred at lower temperatures of 60 , for which these values were 107 and $304^{\circ} \mathrm{C}$ respectively. Thus, $\mathrm{Ag}-\mathrm{Al}_{2} \mathrm{O}_{3}$ behaves uniquely for $\mathrm{NO}$ reduction in presence of $\mathrm{H}_{2}$.

The high catalytic performance of $\mathrm{Ag} / \mathrm{Al}_{2} \mathrm{O}_{3}$ can be explained on the basis of $\mathrm{Ag}$ loading and the Ag physical and chemical states. It is reported by several authors that 2 wt.\% Ag loading is optimum and contains $\mathrm{Ag}$ in the +1 oxidation state [40-42]. The same Ag loading is followed in the present experiment, resulting in formation of $\mathrm{Ag}^{+}$species as evidenced by XRD and XPS studies. It is reported in literature by Shibata et al. [39] that $\mathrm{H}_{2}$ enhance the ratedetermining step and prevents active sites from strongly adsorbed species (e.g. nitrates) at low temperature. $\mathrm{H}_{2}$ addition results in a decreased activation energy for $\mathrm{NO}_{\mathrm{x}}$ reduction. Further, $\mathrm{H}_{2}$ promotes indirectly the SCR-NO $\mathrm{NO}_{\mathrm{x}}$ through the changes in some states of the active catalyst but $\mathrm{H}_{2}$ itself is not active as it is neither a reducing agent nor an intermediate species.

\section{Conclusions}

LPG is a better reductant in comparison to $\mathrm{CO}$ for $\mathrm{NO}$ reduction over $\mathrm{Ag}-\mathrm{Al}_{2} \mathrm{O}_{3}$ catalyst at low temperature. Addition of $\mathrm{H}_{2}$ to the LPG, further reduces the NO reduction temperature. With LPG reductant 100\% NO conversion can be achieved in presence of $\mathrm{H}_{2}$ as well as in absence of $\mathrm{H}_{2}$ but at different temperatures. The $100 \%$ conversion with LPG reductant in presence of $\mathrm{H}_{2}$ was achieved at far lower temperature $\left(117^{\circ} \mathrm{C}\right)$ than without $\mathrm{H}_{2}\left(220^{\circ} \mathrm{C}\right)$. LPG has several advantages over other $\mathrm{HCs}$ such as easily available, economic market price and envi-

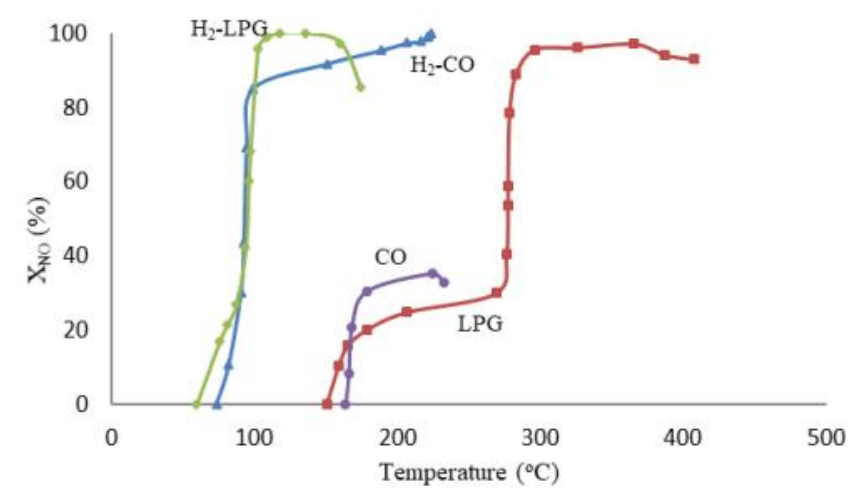

Figure 7. Comparison of with and without $\mathrm{H}_{2}$ assisted NO-SCR over $\mathrm{Ag} / \mathrm{Al}_{2} \mathrm{O}_{3}$ catalyst with (•) $\mathrm{H}_{2}-\mathrm{LPG},(\boldsymbol{\Delta}) \mathrm{H}_{2}-\mathrm{CO},(\bullet) \mathrm{CO}$ and (•) LPG ronment friendly characteristics. LPG being gas at ambient condition no pump is required to feed it in the SCR unit. There is no noticeable change in the characteristics of the fresh and used 2 wt.\% $\mathrm{Ag} / \mathrm{Al}_{2} \mathrm{O}_{3}$ catalyst under the conditions studied in the present investigation. Therefore, it is proposed that $\mathrm{H}_{2}$-LPG-SCR of $\mathrm{NO}_{x}$ over $\mathrm{Ag} / \mathrm{Al}_{2} \mathrm{O}_{3}$ catalyst is a good system for low temperature control of $\mathrm{NO}_{\mathrm{x}}$ emissions.

\section{Acknowledgement}

The authors are grateful to Department of Chemical Engineering and Technology, IIT (BHU), Varanasi and Department of Physics, BHU, Varanasi for extending all necessary facilities to undertake the work.

\section{References}

[1] Koebel, M., Elsener, M., Kleemann, M. (2000). Urea-SCR: A Promising Technique to Reduce NOx Emissions from Automotive Diesel Engines. Catalysis Today, 59(3-4): 335345 .

[2] Satokawa, S. (2000). Enhancing the $\mathrm{NO} / \mathrm{C}_{3} \mathrm{H}_{8} / \mathrm{O}_{2}$ Reaction by Using $\mathrm{H}_{2}$ over $\mathrm{Ag} / \mathrm{Al}_{2} \mathrm{O}_{3}$ Catalysts under Lean-Exhaust Conditions. Journal of Chemistry Letters, 29: 294295.

[3] Houel V., Millington P., Rajaram R., Tsolakis A. (2007a).Promoting functions of $\mathrm{H}_{2}$ in diesel-SCR over silver catalysts. Applied Catalysis B: Environmental, 77: 29-34.

[4] Houel V., Millington P., Rajaram R., Tsolakis A. (2007b).Fuel effects on the activity of silver hydrocarbon-SCR catalysts. Applied Catalysis B: Environmental, 73: 203-207.

[5] Shimizu K., Satsuma A. (2007).Hydrogen assisted Urea-SCR and $\mathrm{NH}_{3}$-SCR with Silver Alumina as highly active and $\mathrm{SO}_{2}$-tolerant de-NOx catalysis. Applied Catalysis B: Environmental, 77: 202-205.

Table 3. Characteristic temperatures $\left(T_{i}\right.$ and $T_{\text {max }}$ ) for $\mathrm{NO}$ reduction over $\mathrm{Ag}-\mathrm{Al}_{2} \mathrm{O}_{3}$ catalysts using CO and LPG as reductants with and without $\mathrm{H}_{2}$-assisted

\begin{tabular}{lccc}
\hline $\begin{array}{c}\text { Reductant / } \\
\text { Promoter }\end{array}$ & $\begin{array}{c}\text { NO Reduction } \\
(\%)\end{array}$ & $T_{i}\left({ }^{\circ} \mathrm{C}\right)$ & $\begin{array}{l}T_{\max } \\
\left({ }^{\circ} \mathrm{C}\right)\end{array}$ \\
\hline $\mathrm{CO}$ & 35 & 163 & 224 \\
$\mathrm{LPG}$ & 97 & 150 & 365 \\
$\mathrm{CO}$ and $\mathrm{H}_{2}$ & 99 & 73 & 220 \\
$\mathrm{LPG}$ and $\mathrm{H}_{2}$ & 100 & 60 & 117 \\
\hline
\end{tabular}


[6] Shimizu K., Tsuzuki M., and Satsuma A. (2007). Effects of Hydrogen and Oxygenated Hydrocarbons on the Activity and $\mathrm{SO}_{2}$ tolerance of $\mathrm{Ag} / \mathrm{Al}_{2} \mathrm{O}_{3}$ for Selective Reduction of NO. Applied of Catalysis B: Environmental 71: 80-84.

[7] Strom, L., Carlsson, P.-A., Skoglundh, M., Harelind, H. (2016). Hydrogen-Assisted SCR of $\mathrm{NO}_{\mathrm{x}}$ over Alumina-Supported Silver and Indium Catalysts Using $\mathrm{C}_{2}$-Hydrocarbons and Oxygenates. Applied Catalysis B: Environmental, 181: 403-412.

[8] Shi, X., Yu, Y., He, H., Shuai, S., Dong, H. and Li, R., (2008). Combination of biodieselEthanol-Diesel fuel blend and SCR catalyst assembly to reduce emissions from a HeavyDuty Diesel Engine. Journal of Environmental Sciences, 20(2): 177-182.

[9] Breen, J.P., Burch, R., Hardacre, C. and Hill, C.J., (2005). Structural investigation of the promotional effect of hydrogen during the selective catalytic reduction of $\mathrm{NO}_{\mathrm{x}}$ with hydrocarbons over $\mathrm{Ag} / \mathrm{Al}_{2} \mathrm{O}_{3}$ catalysts. Journal of Physical Chemistry B, 109(11): 4805-4807.

[10] He, H., Zhang, X., Wu, Q., Zhang, C., Yu, Y. (2008). Review of $\mathrm{Ag} / \mathrm{Al}_{2} \mathrm{O}_{3}$-Reductant System in the Selective Catalytic Reduction of $\mathrm{NO}_{\mathrm{x}}$. Catalysis Surveys from Asia, 12: 38-55.

[11] Sitshebo, S.W.T. (2010). HC-SCR of $\mathrm{NO}_{\mathrm{x}}$ emissions over $\mathrm{Ag}-\mathrm{Al}_{2} \mathrm{O}_{3}$ catalysts using diesel fuel as a reductant. PhD. Thesis, School of Mechanical Engineering, The University of Birmingham.

[12] Kim, M.K., Kim, P.S., Baik, J.H., Nam, I.-S., Cho, B.K., Oh, S.H. (2011). De-NO $\mathrm{N}_{\mathrm{x}}$ Performance of $\mathrm{Ag} / \mathrm{Al}_{2} \mathrm{O}_{3}$ Catalyst Using Simulated Diesel Fuel-Ethanol Mixture as Reductant. Applied Catalysis B: Environmental,105: 1-14.

[13] Korhonen, S.T., Beale, A.M., Newton, M.A., Weckhuysen, B.M. (2011). New Insights into the Active Surface Species of Silver Alumina catalysts in the Selective Catalytic Reduction of NO. The Journal of Physical Chemistry C, 115: 885-896.

[14] Shimizu, K.I., Satsuma, A. (2006). Selective catalytic reduction of NO over supported silver catalysts-practical and mechanistic aspects. Physical Chemistry Chemical Physics, 8: 2677-2695.

[15] Kannisto, H., Ingelsten, H.H., Skoglundh, M. (2009). Ag- $\mathrm{Al}_{2} \mathrm{O}_{3}$ catalysts for lean $\mathrm{NO}_{\mathrm{x}}$ reduction Influence of preparation method and reductant. Journal of Molecular Catalysis A: Chemical, 302(1-2): 86-96.

[16] Kannisto, H., Arve, K., Pingel, T., Hellman, A., Harelind, H., Eranen, K., Olsson, E., Skoglundh, M., Murzin, D.Y. (2013). On the performance of $\mathrm{Ag} / \mathrm{Al}_{2} \mathrm{O}_{3}$ as $\mathrm{HC}-\mathrm{SCR}$ catalyst influence of silver loading, morphology and nature of the reductant. Catalysis Science \& Technology, 3: 644-653.

[17] Härelind, H., Gunnarsson, F., Vaghefi, S.M.S., Skoglundh, M., Carlsson, P.A. (2012). Influence of the Carbon-Carbon Bond Order and Silver Loading on the Formation of Surface Species and Gas Phase Oxidation Products in Absence and Presence of $\mathrm{NO}_{\mathrm{x}}$ over Silver-Alumina Catalysts. ACS Catalysis, 2(8): 1615-1623.

[18] Azis, M.M., Härelind, H., Creaser, D. (2015). On the role of $\mathrm{H}_{2}$ to modify surface $\mathrm{NO}_{x}$ species over $\mathrm{Ag}-\mathrm{Al}_{2} \mathrm{O}_{3}$ as lean $\mathrm{NO}_{\mathrm{x}}$ reduction catalyst: TPD and DRIFTS studies. Catalysis Science \& Technology, 5: 296-309.

[19] Shimizu, K.I., Satsuma, A. (2006). Selective catalytic reduction of NO over supported silver catalysts-practical and mechanistic aspects, Physical Chemistry Chemical Physics, 8: 2677-2695.

[20] Yunbo Yu, Hong He, QingcaiFeng, HongweiGao, Xin Yang, (2004). Mechanism of the selective catalytic reduction of $\mathrm{NO}_{\mathrm{x}}$ by $\mathrm{C}_{2} \mathrm{H}_{5} \mathrm{OH}$ over $\mathrm{Ag} / \mathrm{Al}_{2} \mathrm{O}_{3}$, Applied Catalysis B: Environmental, 49: 159-171.

[21] Yu, Y., He, H., Zhang X., Deng, H. (2014). A common feature of $\mathrm{H}_{2}$-assisted HC-SCR over $\mathrm{Ag} / \mathrm{Al}_{2} \mathrm{O}_{3}$. Catalysis Science \& Technology, 4: 1239-1245.

[22] Kannisto, H., Ingelsten, H.H., Skoglundh, M. (2009). Aspects of the Role of Hydrogen in $\mathrm{H}_{2}$ Assisted HC-SCR Over $\mathrm{Ag}-\mathrm{Al}_{2} \mathrm{O}_{3}$, Topics in Catalysis, 52: 1817-1820.

[23] Guo, Y., Chen J., Kameyama, H. (2011). Promoted Activity of the Selective Catalytic Reduction of NOx with Propene by $\mathrm{H}_{2}$ Addition over a Metal-Monolithic Anodic AluminaSupported Ag Catalyst. Applied Catalysis A: General, 397: 163-170.

[24] Satokawa, S., Shibata, J., Shimizu, K.I., Satsuma A., Hattori, T. (2003).Promotion effect of $\mathrm{H}_{2}$ on the low temperature activity of the selective reduction of NO by light hydrocarbons over $\mathrm{Ag} / \mathrm{Al}_{2} \mathrm{O}_{3}$. Applied Catalysis B: Environmental, 42: 179-186.

[25] Sazama, P., Cyapek, L., Drobna, H., Sobalik, Z., Dedecek, J., Arve, K., Wichterlova, B. (2005). Enhancement of decane-SCR-NO over Ag/alumina by hydrogen. Reaction kinetics and in situ FTIR and UV-vis study. Journal of Catalysis, 232: 302-317.

[26] Eranen, K., Klingstedt, F., Arve, K., Lindfors, L.E., Murzin, D.Y. (2004). On the mechanism of the selective catalytic reduction of $\mathrm{NO}$ with higher hydrocarbons over a silver/alumina catalyst. Journal of Catalysis, 227: 328-343.

[27] Satokawa, S., Shibata, J., Shimizu, K.I. Satsuma, A., Hattori, T., Kojima,T. (2007). Pro- 
motion effect of hydrogen on lean $\mathrm{NO}_{\mathrm{x}}$ reduction by hydrocarbons over $\mathrm{Ag} / \mathrm{Al}_{2} \mathrm{O}_{3}$ catalyst, Chemical Engineering Science 62: 5335-5337.

[28] Wichterlova, B., Sazama, P., Breen, J.P., Burch, R., Hill, C.J., Capek L., Sobalik, Z. (2005). An in situ UV-vis and FTIR spectroscopy study of the effect of $\mathrm{H}_{2}$ and $\mathrm{CO}$ during the selective catalytic reduction of nitrogen oxides over a silver alumina catalyst. Journal of Catalysis, 235: 195-200.

[29] Breen, J.P., Burch, R., Hardacre, C., Hill, C.J. (2005). Structural Investigation of the Promotional Effect of Hydrogen during the Selective Catalytic Reduction of $\mathrm{NO}_{\mathrm{x}}$ with Hydrocarbons over $\mathrm{Ag} / \mathrm{Al}_{2} \mathrm{O}_{3}$ Catalysts, The Journal of Physical Chemistry B, 109: 4805-4807.

[30] Shibata, J., Shimizu, K.I., Satokawa, S., Satsuma A., Hattori, T. (2003).Promotion effect of hydrogen on surface steps in SCR of NO by propane over alumina-based silver catalyst as examined by transient FT-IR. Physical Chemistry Chemical Physics, 5: 2154-2160.

[31] Wang, J., He, H., Feng, Q., Yu, Y., Yoshida, K. (2004). Selective catalytic reduction of $\mathrm{NO}_{x}$ with $\mathrm{C}_{3} \mathrm{H}_{6}$ over an $\mathrm{Ag} / \mathrm{Al}_{2} \mathrm{O}_{3}$ catalyst with a small quantity of noble metal, Catalysis Today, 93-95: 783-789.

[32] Agostino, C.D., Chansai, S., Bush, I., Gao, C., Mantle, M.D., Hardacre, C., James S.L., Gladden, L.F. (2016). Assessing the effect of reducing agents on the selective catalytic reduction of $\mathrm{NO}_{x}$ over $\mathrm{Ag} / \mathrm{Al}_{2} \mathrm{O}_{3}$ catalysts. Catalysis Science \& Technology, 6:1661-1666.

[33] Yu, Y., He, H., Zhang X., Deng, H. (2014). A common feature of $\mathrm{H}_{2}$-assisted $\mathrm{HC}$-SCR over $\mathrm{Ag} / \mathrm{Al}_{2} \mathrm{O}_{3}$, Catalysis Science \& Technology, 4: 1239-1239.

[34] PaÃrvulescu, V.I., Grange, P., Delmon. B.(1998). Catalytic removal of NO. Catalysis Today, 46: 233-316.
[35] Kim, M.C. (2012). De-NOx by SCR (Selective Catalytic Reduction) Using LPG as a Reductant, Applied Chemistry for Engineering, 23 (6): 588-593.

[36] Chaieb, T., Delannoy, L., Costentin, G., Louis, C., Casale, S., Chantry, R.L., Li, Z.Y., Thomas, C. (2014). Insights into the influence of the $\mathrm{Ag}$ loading on $\mathrm{Al}_{2} \mathrm{O}_{3}$ in the $\mathrm{H}_{2}$-assisted $\mathrm{C}_{3} \mathrm{H}_{6}-\mathrm{SCR}$ of $\mathrm{NO}_{\mathrm{x}}$. Applied Catalysis B: Environmental, 156: 192-201.

[37] Hammond, J.S., Gaarenstroom, S.W., Winograd, N. (1975). X-ray Photoelectron Spectroscopic Studies of Cadmium and SilverOxygen Surfaces. Analytical Chemistry, 47: 2193-2199.

[38] Erkfeldt, S., Palmqvist, A., Petersson, M. (2011). Influence of the reducing agent for lean $\mathrm{NO}_{\mathrm{x}}$ reduction over Cu-ZSM-5, Applied Catalysis B: Environmental, 102: 547-554.

[39] Shibata, J., Shimizu, K., Satokawa, S., Satsuma, A., Hattori, T. (2003). Promotion effect of hydrogen on surface steps in SCR of NO by propane over alumina-based silver catalyst as examined by transient FT-IR. Physical Chemistry Chemical Physics 5: 2154-2160.

[40] Miyadera, T.(1993). Alumina-supported silver catalysts for the selective reduction of nitric oxide with propene and oxygen containing organic compounds. Applied Catalysis B: Environmental, 2: 199-205.

[41] Bethke, K.A., Kung, H.H. (1997). Supported $\mathrm{Ag}$ catalysts for the lean reduction of NO with $\mathrm{C}_{3} \mathrm{H}_{6}$. Journal of Catalysis, 172: 93-102.

[42] Hoost, T.E., Kudla, R.J., Collins, K.M., Chattha, M.S. (1997). Characterization of $\mathrm{Ag} / \gamma-\mathrm{Al}_{2} \mathrm{O}_{3}$ catalysts and their lean- $\mathrm{NO}_{x}$ properties, Applied Catalysis B: Environmental, 13: 59-67. 